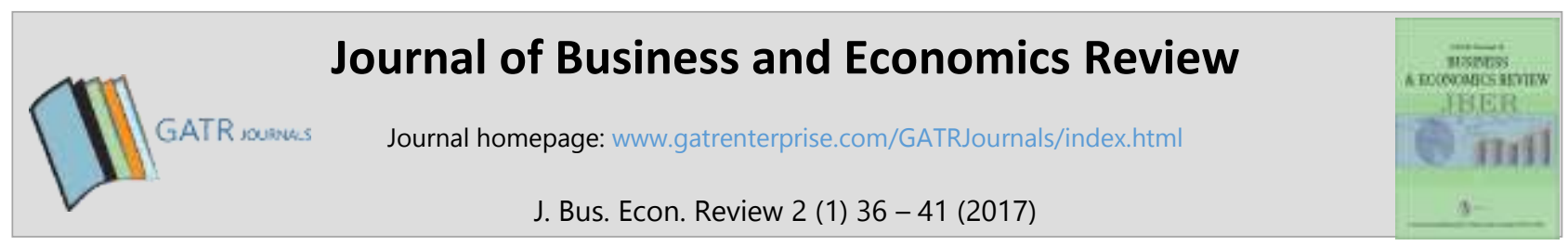

\title{
Settling Inconsistencies Associated with The Genesis of The Financial Services Authority Act
}

\author{
Theresia Anita Christiani ${ }^{1 *}$ and Maria Hutapea ${ }^{2}$ \\ 1,2 Universitas Atma Jaya Yogyakarta, 55281, Yogyakarta , Indonesia
}

\begin{abstract}
Objective - The FSA Act the establishment of which is mandated by Article 34 of Law No. 23 of 1999 concerning the Bank of Indonesia, was enacted on 22 November 2011. This Act, together with Law No. 3 of 2004, regulates and supervises Indonesia's integrated financial services sector. This article reveals the existence of inconsistencies between the legal terms underlying the establishment of the FSA one the one hand, and the provisions contained in the Financial Service Authority itself, on the other. These inconsistencies also become evident in the light of the 1945 Constitution which facilitated the establishment of the Bank of Indonesia Law. The purpose of this article is to ascertain a method of resolving these inconsistencies associated with the genesis of the Financial Service Authority.

Methodology/Technique - The research method used in this article is doctrinal in nature that uses secondary data and information sources as material to analyse the relevant problems.

Findings - The research has revealed that the most appropriate method of settling these inconsistencies requires a consideration of the express wording of the FSA.

Novelty - This article indicates the need to apply legal principles rather and adjudicatory methods.

Type of Paper: Review
\end{abstract}

Keywords: Settlement; Banking; Legal; Principle; Law.

JEL Classification: J21, J28, K23.

\section{Introduction}

The legal basis of Law No. 21 of 2011 on Financial Services Authority (FSA) is explicitly stated in Article 34 of Law No. 23 of 1999 concerning Bank Indonesia (BI) and the explanation about it. In its development, Law No. 23 of 1999 was amended by the enactment of Law No. 3 of 2004. In fact there are legal inconsistencies that arise from the basic regulation of the emergence of FSA Law, that are 1945 Constitution (UUD 1945) and BI Law. Legal inconsistencies in form of philosophical matters between 1945 Constitution and Financial Service Authority Law, and between Bank Indonesia Law and Financial Service Authority Law will disrupt the duties and objectives of Financial Service Authority set forth in Financial Service Authority Law. The urgency of this research is the legal inconsistencies of the emergence of Financial Service Authority Law with

\footnotetext{
* Paper Info: Received: February 4, 2017

Accepted: March 23, 2017

* Corresponding author:

E-mail: thanita@mail.uajy.ac.id

Affiliation: Universitas Atma Jaya Yogyakarta, Indonesia.
} 
1945 Constitution and Bank Indonesia Law that will result in the disability of Financial Service Authority emergence objectives to achieve. Disharmony of legislation will result in the occurrence of interpretation differences in the implementation, legal uncertainty, inapplicable legislation effectively and efficiently, and legal dysfunction meaning law cannot function as the guidance of public behaviour social control, and disputes settlement (Susetio, 2013). Based on that concern, the specific objective of this research is to find the most appropriate approach method to understand and address the legal inconsistencies in the emergence of Financial Service Authority Law.

\section{Research Methodology}

This research is the study of law in the realm of normative juridical/doctrinal. Doctrinal legal research is an inventory attempt of positive law, a finding of the principles and basic philosophy of positive law, and efforts to find inconrito law (Wignyosoebroto, 1994). This research uses legislative approach to seek the ratio legis and ontological basis of each chapter and the Law as a whole. The types of data in this research are secondary data, literature data or law materials. Law materials consist of primary, secondary, and tertiary law materials.

Data collection techniques of this research are conducted by literature study toward the primary, secondary, as well as tertiary law materials, and interviews with the interviewees that will complement the secondary data. In testing the used data trustworthiness, this research uses triangulation technique (Moleong, 1995). The obtained data will be analysed using qualitative analysis.

\section{Research and Discussion}

\subsection{Legal Inconsistencies}

Legal inconsistencies are divided into: (Susetio, 2013):

1. Vertical Inconsistency

It is an inconsistency between higher regulations and lower regulations. The sort order of regulations is stipulated in Law No. 12 of 2011 on the Establishment of Legislation.

2. Horizontal Inconsistency

It is an inconsistency between regulations with other regulations within the same level or an inconsistency between the laws of the same level.

\subsection{Legal Inconsistency in the Existence of Financial Service Authority Act Law}

First: The legal inconsistency between 1945 Constitution and Financial Service Authority Law can be seen from Article $23 \mathrm{D}$ of 1945 Constitution and its amendment. The article, among other things, mentions that Indonesia has a Central Bank in which the arrangement and position, authority and responsibility and independence regulated by law. The provisions of Article $23 \mathrm{D}$ of the 1945 Constitution and the Amendment essentially want the presence of an independent central bank regardless of intervention from any parties in performing tasks and achieving its objectives. In the implementation, Article 6 and Article 7 of Financial Service Authority Law give authority to Financial Service Authority to conduct regulatory and supervisory tasks. Such provision will obscure the meaning of independence of Bank Indonesia as the central bank as mandated by Article 23 of 1945 Constitution. The obscurity of the meaning of independence happens because when referring to the meaning of independence, it means Bank Indonesia as a central bank is independent in performing the duties and objectives with no interference from any parties. By the transition of duties in regulating and supervising banking institutions, it means Bank Indonesia is dependent in performing its duties. The meaning of independence of Bank Indonesia as a central bank as contained in Law relating to Banking 
(Bank Indonesia Law and Banking Law) becomes irrelevant anymore. That is to say that a shift in the meaning of independence of Bank Indonesia as the central bank as mandated by the 1945 Constitution.

Second: The legal inconsistency between Bank Indonesia Law and Financial Service Authority Law can be seen from Article 34 Paragraph 1 of Bank Indonesia Law and the explanation stating the duties for supervising banks will be conducted by an independent regulator of financial services established by law. The duty of regulating will still be conducted by Bank Indonesia . However, in reality Article 6 and Article 7 of FSA Law mandate that duties transferred from Bank Indonesia are regulation and supervision. It is inconsistent with Article 34 of Bank Indonesia Law.

\subsection{Impacts of Legislation Inconsistency}

\subsubsection{Juridical Impact}

Disharmony of legislation will result in the occurrence of interpretation differences in the implementation, legal uncertainty, inapplicable legislation effectively and efficiently, and legal dysfunction meaning law cannot function as the guidance of public behavior social control, and disputes settlement (Susetio, 2013).

\subsubsection{Substantive Impact}

The inclusion of an independent central bank carrying out policy in monetary is very relevant for the constitution. It is also based on two things. First, the central bank should have a strong basic in performing its duties and objectives. By implementing the duties and meeting the objectives, Bank Indonesia will bring an enormous influence of economic fundamentals in Indonesia. Second, the history of banking and economy in Indonesia proves the dependency of BI set forth in the Banking Law before 1998 and Bank Indonesia Law prior to Law No. 23 of 1999 resulted in a banking crisis. This crisis led to the financial crisis in 1997 devastating the lives of the economy as a whole. At times of severe economics crisis and recession, selecting types of selfregulation over political control can be a particularly dangerous route to follow (Glinavos, 2014). It is proper that the independent position of Bank Indonesia is set forth both in constitution and Laws related to Banking. The impact of the Financial Service Authority Law inconsistencies is the shift of independence meaning as set forth in Banking Law and Bank Indonesia Law. An attempt for the resolution is by considering Amendments to Law relating to Banking, particularly related Articles, in order to keep the certainty and consistency of the existing Laws Based on Article 6 and Article 7 of Financial Service Authority Law, Financial Service Authority has the authority to perform the duties of supervising and regulating banking institutions. As known, the explanation of Article 7 of Financial Service Authority Law states that regulation and supervision of institution, health, prudential aspects, and the bank examination are micro-prudential becoming the duties and authority of Financial Service Authority. For macro-prudential regulation and supervision, namely those not set forth in this Article, they are the duties and authority of BI. In the framework of macro-prudential regulation and supervision, FSA helps BI to make moral appeals to Banking. The impact of macro and micro-prudential authority separation is the inexistence of authority to supervise. Thus, Bank Indonesia will lose one of the important factors to the successful monetary management and policy. Theory of credit channel in the monetary literature is still very strong because banks still control $80 \%$ of the national financing. Banking appears inherently risky (Harison, 2014). Therefore, with these considerations, the Bank Supervision remained under the Governor of Bank Indonesia is constructed as the best way to the stabilization and effectiveness of banking supervision micro-prudential. The access to information of micro-prudential conditions should be given to the authorities responsible for macro-prudential issues despite the existence of FSA. Without a fast, accurate and easy access, the duties of macro-prudential will not succeed. The need for this authority should really exist, not only because of other institution mercy. When the crisis largely begins to occur, the process regarding the tug of the access will destroy market confidence and trigger another crucial problem, which is institutional distrust. How will the crisis be overcome if state agencies responsible for 
economic issues warring each other? If this process is not set, the institutional barriers will be a serious obstacle in the formulation of a proper and fast policy on the crisis and policy implementation in public. This is a critical point if FSA Law is enacted without access guarantees to Bank Indonesia to directly monitor the banking condition (Mongid, 2010).

From the description, it can be reviewed that the authority of Bank Indonesia to perform the banking macroprudential regulation and supervision duties cannot be implemented without direct banking access guarantee in banking. The absence of barriers between agencies is a condition of the successful implementation of the micro supervision and regulation transitional authority from Bank Indonesia to Financial Service Authority.

\subsection{Method of Legal Settlement against Existing Inconsistencies}

\subsubsection{Juridical Settlement Method}

In the legislation inconsistency, generally there are three ways to overcome this as follows:

Change or repeal certain disharmony articles or whole concerned legislation articles by the institution/ agency having the authority to formulate them.

- Apply for a judicial review to the judiciary as follows:

○ To test the law against Constitution to Constitutional Court

- To test the legislation under the laws against the laws to Supreme Court

- Apply the principles of law/legal doctrine as follows:

- Lex superior derogate legi inferiori

It means that higher-level legislations override lower-level legislations, unless the higher-level legislation substance regulates the matters that by law are set to be lower-level legislation authority (Manan, 2014).

- Lex specialis derogate legi generalis

This principle implies that a special law will override the common law.

There are several principles to be considered in Lex specialis derogate legi generalis (Manan, Bagir. 2014)

- The provisions found in the common law rules are still applicable, unless those specifically regulated in the special law.

- The provisions of lex specialis should be equal with the provisions of lex generalis (legislations with legislations).

- The provisions of lex specialis must be in the legal environment (regime) equal to lex generalis. The Code of Commercial Law and the Code of Civil Law include in civil legal environment.

- Lex posterior derogate legi priori

It means that the newer legal rules override or negate the old laws. The principle of lex posterior derogate legi priori requires the use of the new law.

This principle also contains the principles as below (Manan, 2014)

- The new legal rules should be equal or higher than the old legal rules.

- The new and old legal rules regulate the same aspects.

This principle is intended to prevent the dualism which is able to create legal uncertainty. With the principle of Lex posterior derogate legi priori, the provisions governing revocation of legislation do not truly matter. By law, the similar old provisions will no longer be applied when the new legal rules prevail (Manan, 2014) 
The next description will associate a general description of legal settlement method when legal regulation inconsistency and legal inconsistency issues on FSA Law existence happen. The legal inconsistency of FSA Law existence with 1945 Constitution is a vertical inconsistency. It is an inconsistency between higher-level legislations to lower-level legislations. According to Law No. 12 of 2011, it is stated that 1945 Constitution has a higher level than Law. Legal inconsistency between the FSA Law and BI Law is a horizontal inconsistency. It is an inconsistency occur in among the same-level legislations. The proposed settlement methods are juridical and non-juridical/substantive settlement methods. Judicial settlement method with both vertical and horizontal inconsistencies is firstly conducted by changing or repealing disharmony articles or the whole concerned legislations by the institutions or agencies having the authority to formulate them. The second way is to apply for a judicial review to the judiciary as follows:

- To test the law against Constitution to Constitutional Court

- To test the legislation under the laws against the laws to Supreme Court

Then, the third way is to apply the principles of law or legal doctrine.

The first and the second juridical settlement methods are certainly not an easy thing to do and require more time and energy because many factors, both legal and political, will undoubtedly dominate this effort. Meanwhile, legal certainty and society growth demand more for legal certainty. Considering to this situation, the third legal settlement method or the application of the principle of law/legal doctrine are a possible efforts to do.

\subsubsection{Substantive Settlement Method}

Substantive completion method means that efforts can be made by changing the inconsistent law materials in order not to interfere the objectives of the law establishment.

\section{Conclusion}

Legal Inconsistencies are divided into vertical inconsistency and horizontal inconsistency. There are legal inconsistencies about the existence of Financial Services Authority Law. The legal inconsistencies are between 1945 Constitution and Financial Service Authority Law, and between Financial Service Authority Law and Bank Indonesia Law.

The impacts of legal inconsistencies of Financial Service Authority are juridical impact and substantive impact. Disharmony of legislation will result in the occurrence of interpretation differences in the implementation, legal uncertainty, inapplicable legislation effectively and efficiently, and legal dysfunction meaning law cannot function as the guidance of public behavior social control and disputes settlement Legal inconsistencies will disturb duties implementation of Bank Indonesia. It should be tested to the constitutional court for legal inconsistencies between FSA law and our constitution. It should be applied the principles of law legal doctrine for legal inconsistencies between Financial Service Authority Law and Bank Indonesia Law.

\section{References}

Glinavos. I, (2014), Redefining the Market-State Relationship, New York, Routledge. Harison, D (2014), Competition Law and Financial Services, New York, Routledge

Mongid, EA (2010). Independensi Pengawasan Bank dan Stabilitas SistemKeuangan [Independence of Banking Supervision and the Financial System Stability]. Buletin Hukum Perbankan dan Kebanksentralan, 8, 33.

Manan, B, (2014), Hukum Positif Indonesia [Indonesian Positive law]. Yogyakarta, UII Press.

Moleong, L.J. (1995). Metodologi Penelitian Kualitatif [Qualitative Research Methodology]. Bandung, Remaja Rosdakarya.

Susetio, W. (2013). Disharmoni Peraturan Perundang-Undangan di Bidang Agraria, [Regulation Legislation disharmony 
in the Agricultural Sector]. Lex Jurnalica, 10, 142-143.

Wignyosoebroto, S. (1994), Masalah Metodologik Dalam Penelitian Hukum Sehubungan Dengan Masalahnya,

Keragaman Pendekatan Konseptual [Methodological problems in Legal Research Relating Diversity Conceptual Approach]. Dirjen Dikti, Jakarta

Constitution of Republic Indonesia. (1945)

Law No. 12 of 2011 on Establishment of Legislation

Law No 21 of 2011 on Authority Service Act.

Law No 23 of 1999 is Amendment with Law No 3 of 2004 on Bank Indonesia 